\section{Robert E. Martin}

Robert E. Martin, professor emeritus, died of cancer on January 31, 1993 at his home in St. Augustine, Florida. He was a leading figure in the department of political science at Howard University for many years. He did his undergraduate work at Howard, receiving the bachelor's degree, with a major in political science, in 1936. He was awarded the master's degree at Howard in 1938. His master's thesis was on Negro disfranchisement in Virginia. It was considered so outstanding that it was published by the Social Sciences Division. He received the Ph.D. degree from the University of Chicago after writing a significant dissertation on Negro-white participation in the AAA Cotton and Tobacco Referendum. He accomplished the field research involved in this dissertation with the assistance of a grant from the Social Science Research Council. He interviewed hundreds of black and white farmers in North Carolina and South Carolina. In addition to the award from the Social Science Research Council, he received grants from the Rosenwald Foundation and the Ford Foundation.

Beginning with an appointment to the faculty of North Carolina A\&T University, he had an extensive teaching career. He joined the faculty of Howard in 1947 and remained there until formal retirement in 1977. However, he continued to teach part time at Howard until 1985. Along the way, he taught part time at Columbia University, New York University, Atlanta University, Southern Illinois University, and the University of San Francisco. His particular area of study was American government and politics, with emphasis upon voting behavior.

During World War II, Dr. Martin worked with the Office of War Information. He served on the District of Columbia Board of Elections for a number of years, and for a time was its chairman. Over a period of years he supervised a number of community elections in the city. He directed a Peace Corps training project for one year and held the position of associate dean of the College of Liberal Arts for two years.
He was a member of Phi Beta Kappa and Pi Sigma Alpha. He was a vice president of the American Political Science Association and president of the National Capitol Area Political Science Association. His membership in various community organizations was extensive. He was a frequent lecturer to foreign visitors at the Washington International Center.

Faculty and students who were fortunate to work with him will especially remember him as a gifted teacher. He was a true believer in high standards. He worked in the tradition of two of his teachers and pace setters in this departmentRalph Bunche and Emmett Dorsey. In Dr. Martin's passing, the department, the profession, and the community have suffered a grievous loss.

Vincent Browne

Howard University

\section{Judith Shklar}

Judith Nisse Shklar, the Johns Cowles Professor of Government at Harvard University, died of a heart attack, in Boston, on September 17, 1992. She was born in Riga (Latvia) on September 24, 1928. Her parents were of German Jewish origin. As World War II was about to begin, and the fate of the Baltic states was being settled by the Hitler-Stalin deal of August 1939, the family moved to Sweden. When Hitler, having occupied Denmark and Norway, appeared ready to move on Sweden, they left Europe and traversed the Soviet Union all the way to Vladivostok. From there they sailed to Japan and left for the United States shortly before Pearl Harbor. They landed in Seattle just after the Japanese attack, and were briefly jailed as enemy aliens. Released, they went to Canada, where Dita Shklar's father bought a farm. She studied economics at McGill University, where she met her husband, a medical student (now professor of oral pathology at Harvard's Medical School), and where Professor Frederick Watkins appreciated her gift for political philosophy. He recommended that she apply for graduate study to the Department of Government at Harvard. She was admitted in 1950; she wrote her dissertation under Professor Carl J. Friedrich; it became her first book, After Utopia (Princeton University Press), a sweeping study of the decline of political theory at the end of the 19th and into the 20th century. She was appointed an instructor in 1956 and was promoted to an assistant professorship in 1960. She taught, among other subjects, a course on the history of modern legal theory, which led to her second book, Legalism (Harvard University Press).

Instead of giving her tenure, the Department of Government, whose members were fully aware of her brilliance, settled for a permanent "part-time"' lectureship, which turned out never to be part-time, given her energy, her enthusiasm for teaching, and her ability to be a responsible and fully committed scholar while raising her three children, born in 1955, 1960 and 1965. When Derek Bok became president of Harvard in 1971, he transformed her lectureship into a regular tenured professorship.

Professor Shklar's third and fourth books were powerful and persuasive exegeses of the political thought of Jean-Jacques Rousseau (Men and Citizens, Cambridge University Press, 1969) and of Hegel's Phenomenology of Mind (Freedom and Independence, Cambridge University Press, 1976). She continued to teach the history of political thought, with particular emphasis on the Enlightenment. She also began, in the 1970s, to teach and write on the history of American political thought, especially in the period preceding the Civil War. In the 1980s, she co-taught with this writer a core curriculum course on modern ideologies, and shortly before her death she gave for the first time another core course on political obligation.

In the $1980 \mathrm{~s}$, while continuing to work on specific authors (Montesquieu, Oxford University Press, 1987), she developed her own ideas about what the political and psychological underpinnings of liberalism could be after the atrocities of the twentieth century and the collapse of illusions about progress and reason. Her central idea was the "liberalism of fear," based on the avoidance of what she abhorred above everything else: cruelty. She was fascinated with aspects of politics she deemed essen- 